\title{
Shareholder value maximization: What managers say and what they do
}

\author{
Petra Jörg, Claudio Loderer, ${ }^{*}$ and Lukas Roth \\ Universität Bern, Institut für Finanzmanagement, \\ Engehaldenstrasse 4, CH - 3012 Bern, Switzerland
}

February 19, 2003

Keywords: Shareholder value, Stakeholder value, Managerial targets, Performance

${ }^{*}$ Corresponding author (claudio.loderer@ifm.unibe.ch). Comments are welcome.

We would like to thank the participants of WHU Campus for Finance: "Rationality of stock markets and empirical finance," Koblenz, January 2003. We are also indebted to Christoph Hinkelmann and Urs Peyer for their comments and suggestions. We further benefited from the criticism of Karl Pichler and Pius Zgraggen. Many thanks to Nancy Macmillan for the great editorial help. 


\title{
Shareholder value maximization:
}

\section{What managers say and what they do}

\begin{abstract}
This paper examines whether Swiss firms maximize shareholder value. To find out, we survey the goals of 313 listed and unlisted firms. We then examine whether managers' decisions are consistent with their goals and analyze whether performance corresponds to intentions. Our results show that most managers pursue conflicting targets. Many also declare that they do not maximize shareholder value. And those who claim they do sometimes rely on investment criteria that are inconsistent with that target. Finally, we find that share-price performance is marginally better when managers claim to maximize shareholder value, particularly when stock prices have fallen.
\end{abstract}




\section{Shareholder value maximization: \\ What managers say and what they do}

\section{Introduction}

In many industrialized nations, there is a serious controversy about the purpose of the corporation involving the media, economists, policymakers, and managers (Jensen, 2001). The question is that of the appropriate target or, as Jensen puts it, the scorecard that would allow managers to distinguish what is better from what is worse. Ultimately, the dispute is about whether the corporation should maximize value for shareholders or for stakeholders — or, in many ways, about corporate social responsibility. ${ }^{1}$

This paper examines whether the managers of Swiss corporations pursue shareholder value maximization. To find out, we first ask managers directly. Second, we examine whether they use investment criteria consistent with the goal of maximizing shareholder value. Finally, we investigate whether stock-price performance corresponds to intentions.

In Switzerland, the notion that firms ought to maximize shareholder value appears to be particularly divisive, possibly because of the comparatively low mobility of the population. Low mobility means closer relationships and more frequent opportunities to compare one's financial success with that of friends and acquaintances. To prevent envy and jealousy, society therefore seems to sanction the open accumulation and public display of wealth, and to encourage its sharing. That could also explain why so many people resist the notion that corporations should focus on creating shareholder value, and why they associate shareholder value maximization with greed and expropriation. ${ }^{2}$

1 Stakeholders are usually understood to include shareholders, debtholders, employees, customers, suppliers, the government, and the environment. The Stanford Research Institute defines stakeholders as "those groups without whose support the organization would cease to exist" (cited in Freeman (1984), 31).

2 The chairman of the board of Vontobel Holding, a listed bank, stated at the 1996 shareholder meeting that shareholder value maximization generally occurs at the expense of other stakeholders in the firm. Moreover, he remarked that all those who idealize shareholder value undermine the foundations of society. See Neue Zürcher Zeitung, June 19, 1996, 28. 
As it turns out, shareholder value maximization is a hotly debated issue in other German-speaking countries as well, and in Germany in particular. ${ }^{3}$ The origins of the controversy can be documented as far back as the start of the twentieth century, when the science of management had its beginnings. According to Schmalenbach, for example, the purpose of this science is not to focus on the interests of the providers of capital but rather on how firms establish their social productivity. The current skepticism about shareholder value maximization is reinforced by the fact that, under German law, employee representatives are entitled to sit on the firms' governing boards. ${ }^{4}$ This skepticism is also reflected in German jurisprudence in general: the firm's interests are generally interpreted as being the interests of all parties with a stake (in the general sense of the term) in the firm.

The heart of the debate on whether management should run the corporation solely in the interests of shareholders has been the U.S. Becht, Bolton, and Röell (2002) trace the origins of the academic debate to the first writings on corporate governance (see Berle, 1931, and Dodd, 1932). But the question of corporate social responsibility is as old as the corporation itself, and the answer to that question has swung back and forth from freedom from any obligation other than to obey the law to the requirement that companies pursue the interests of their stakeholders, notably those of the state (see Economist.com, 2002). Although Anglo-Saxon companies are believed to be less constrained than European or Japanese companies to pursue the interests of their shareholders, de facto they face many impediments to do so. In the late $1980 \mathrm{~s}$, for instance, more than half of America's state legislatures adopted "other constituency" statutes that allow directors to consider the interests of all their stakeholders, not just shareholders; Connecticut even passed a law requiring them to do this (Economist.com, 2002). ${ }^{5}$ "It appears that when forced to choose, managers and shareholders alike - as well as most judges and legislators - generally opt for rules that favor director primacy over rules that favor shareholder primacy" (Stout, 2002, 1202).

3 The following information is taken from Wagner (1997).

4 For an analysis of codetermination in Germany, see, for instance, Benelli, Loderer, and Lys (1987).

5 "Delaware gives directors free rein to pursue strategies that reduce shareholder wealth while benefiting other constituencies. Thus, directors can use earnings to raise employees' wages rather than to declare a dividend; they can "reprice" executive stock options even when share prices are falling; they can retroactively increase retirees' pension benefits; and they can donate corporate funds to charity" (Stout, 2002, 1202-1203). 
Unlike in the US, however, the shareholder value maximization debate in German-speaking countries is often ideological, and beliefs are rarely corroborated by facts. ${ }^{6}$ This paper provides some of the facts. It is organized as follows. Section 2 briefly describes the experiment. Section 3 discusses the sample of corporations surveyed and documents response rates and associated descriptive statistics. Sections 4-6 present the results.

Specifically, Section 4 surveys managers' preferences. Surprisingly, managers mention maximization of shareholder value as a goal only about half of the time, and when they do, it is often because share prices have fallen. We also observe that managers give answers that are logically inconsistent by claiming to pursue competing targets at the same time.

Section 5 then examines what criteria managers use when making investment decisions and what approaches they take to value firms. The evidence indicates that managers who claim to adhere to shareholder value maximization are more likely to use a discounted cash flow (DCF) firm-valuation approach. Shareholder-value maximizing managers, however, are not more likely than other managers to rely on the net present value (NPV) investment rule.

Section 6 asks whether managers who say they want to maximize shareholder value also achieve superior stock-price performance. The evidence is marginally consistent with that claim, particularly when stock prices have fallen. Finally, section 7 draws the conclusions.

\section{The experiment}

We rely on a survey of listed and unlisted firms in Switzerland and conduct a three-pronged experiment. We analyze managers' targets, study their valuation metrics, and ask whether share-price performance is better when they pursue shareholder value maximization and use the appropriate metrics. What follows explains these points in more detail.

6 See, for instance, the discussion in the Neue Zürcher Zeitung, Dossier Shareholder Value, 1996. 


\subsection{Managerial targets}

The first part of the analysis focuses on the targets that managers say they pursue. We inquire in particular into the proportion of firms that claim to maximize shareholder wealth. Moreover, we examine possible logical inconsistencies in these claims as well as differences across firm size and between listed and unlisted firms. We ignore the issue of whether shareholder-value maximization makes normative sense for shareholders. Unanimous support for such a policy among shareholders requires a competitive capital market that permits Pareto-optimal allocation (Brennan, 2001).

\subsection{Investment criteria and firm-valuation approaches}

The second part of our investigation reviews the criteria managers use when deciding what projects to invest in and when valuing firms. We examine whether firms that evaluate investment projects on an NPV basis also take a discounted cash flow (DCF) approach when valuing firms. Since both methods compute value on the basis of discounted future cash flows, logical consistency requires that firms that apply the NPV criterion also rely on a DCF approach.

Furthermore, we investigate whether firms that claim to maximize shareholder value also use NPV and DCF in their decisions. The reason to expect such a tie is that both NPV and DCF help firms identify the investment projects with the greatest value added for the firm. Both metrics help managers maximize firm value. And since in efficient capital markets the NPV of investments or acquisitions accrues in large part to shareholders, a policy of firm-value maximization maps into a policy of shareholder value maximization. ${ }^{7}$

7 The exceptions to this rule are cases in which the claims of other parties to the firm (for instance, those of debtholders) are very risky. In those cases, it can be preferable for shareholders to engage in wealth redistribution from other stakeholders even if that means engaging in negative NPV projects (and therefore dissipating firm value). As a first approximation, however, these cases involve mainly firms in financial distress (see, for instance, the discussion in Jensen and Meckling, 1976, and Myers, 1977). Thus, in most cases, the policies of shareholder and firm value maximization coincide, which means that a policy of shareholder value maximization also requires the adoption of the NPV and DCF metrics. 


\subsection{Share-price performance}

The third part of the analysis asks whether the firms of managers who claim to maximize shareholder value and use the appropriate valuation metrics also experience better share-price performance. To gauge whether managers add to shareholder value, we have to establish whether shareholders' wealth grows faster over time than would be required to compensate them for the risk they bear and the time value of money. We therefore measure share-price performance with the abnormal or excess returns experienced by the stockholders of a particular firm during a given period. The capital asset pricing model (CAPM) is our theoretical benchmark in that computation. Abnormal returns are defined as deviations of stock returns from that benchmark.

Specifically, we estimate the following regression equation over the relevant time period:

$$
\mathrm{R}_{\mathrm{it}}-\mathrm{R}_{\mathrm{Ft}}=\alpha_{\mathrm{i}}+\beta_{\mathrm{i}} \times\left(\mathrm{R}_{\mathrm{Mt}}-\mathrm{R}_{\mathrm{Ft}}\right)+\varepsilon_{\mathrm{it}},
$$

where the variables are defined as follows:

$$
\begin{array}{ll}
\mathrm{R}_{\mathrm{it}} & \begin{array}{l}
\text { the continuously compounded rate of return on the stock of firm } \mathrm{i} \\
\text { during month } \mathrm{t} ;
\end{array} \\
\mathrm{R}_{\mathrm{Ft}} & \text { the continuously compounded risk-free rate of return during month } \mathrm{t} ; \\
\mathrm{R}_{\mathrm{Mt}} & \text { the continuously compounded rate of return on the market portfolio } \\
& \quad \text { during month } \mathrm{t} \text {. As a proxy for this variable, we choose the Morgan } \\
& \text { Stanley Composite Index Europe 15 (MSCI-E 15); } \\
= & \text { a serially uncorrelated, normally distributed error term with zero mean } \\
& \text { and constant variance; }
\end{array}
$$

If firm i experiences stock-price performance systematically above or below that predicted by the CAPM during a particular period, its intercept coefficient $\alpha_{i}$ will be significantly different from zero. We perform the estimation with the robust regression approach implemented in Stata 7.8 Robustness is with respect to the distribution assumptions of the error term.

8 StataCorp. 2001. Stata Statistical Software: Release 7.0. College Station, TX: Stata Corporation. 
Compared with other measures of managerial performance that rely on accounting information, excess stock returns have the merit of capitalizing the impact of management decisions on the firm's future cash flows. The implicit assumption is that the stock market is able to compute values correctly on average.

The drawback of abnormal returns is that they reflect investors' expectations. In other words, they capture the impact on share prices of changes in investors' expectations rather than the impact of managerial performance per se. As a consequence, a positive $\alpha_{i}$ simply means that the firm has performed better than expected, but it is not clear what those expectations were. They could have been very optimistic or very pessimistic. If expectations were high, a positive $\alpha_{i}$ would imply truly exceptional performance. Otherwise, a positive $\alpha_{i}$ could reflect poor performance, though better than feared. To mitigate the expectations problem, we estimate the regression equation (1) over longer periods. The rationale for doing so is that, if we assume corrective mechanisms discipline underperforming managers, then over the medium to long term, firms can be expected to perform equally well. If so, a positive $\alpha_{\mathrm{i}}$ measures good performance in relation to a set of expectations that are similar across firms. Thus, firms with a positive $\alpha_{i}$ are firms that have performed well in relation to the rest of the firms in the sample.

\section{Sample characteristics}

We sent the questionnaire in the fall of 1998 to the 2,035 firms reported on the Top 2000 CD-ROM published in 1998 by Handelszeitung, a business weekly. ${ }^{9}$ Of these firms, 184 were listed on the Swiss Stock Exchange and 1,851 were not. To ensure an adequate response, we sent a reminder to all firms (listed firms received two reminders). Three hundred and forty-six firms eventually filled out the questionnaire by the end of 1998 , for a $17 \%$ response rate. Of those, we dropped 33 companies because they did not have the legal form of the private corporation. The remaining 313 companies make up our sample, with the following breakdown: 75 listed firms (response rate of 41\%) and 238 unlisted ones (response rate of 15\%). The listed firms include large multinationals such as Credit Suisse, Nestlé, Novartis, Swiss Re, UBS, and Zürich Financial.

9 The reader will notice that, in spite of its name, the disk contains more than 2,000 companies. 
The sample is not clustered in any one industry, even though most of the companies are in the wholesale, electronics, banking, machinery, and food industries. As for the composition of the sample by size, $33 \%$ of the firms are large, $55 \%$ medium sized, and 12\% small. Small firms have fewer than 50 employees, mediumsized firms between 50 and 499, and large firms 500 or more. Firms have an average of 1,010 employees, and a median of 270. This compares with an average of 2,723 employees in listed firms (with a median of 1,095) and an average of 475 employees in unlisted firms (with a median of 200).

Generally, at least according to the information they provided, fairly high-ranking officers or directors in the firm filled out the questionnaire. That is, a member of the board of directors in $10 \%$ of the cases; a senior manager in $40 \%$; the chief financial officer, the controller, or the treasurer in $43 \%$; and someone else in the firm in the remaining $7 \%$ of the cases. Most of these people should have had the information needed to answer the questions we were asking.

\section{What managers say: The evidence}

Table 1 compiles the answers that managers give when asked whether or not they pursue a given target. Cases with no answer are ignored. Consequently, when the table shows that a given percentage $\pi$ of firms pursues a given target, this also means that a percentage $(1-\pi)$ does not pursue that particular target.

\section{((insert Table 1))}

Before discussing the numbers in the table, we should point out that the target of shareholder value maximization is stated conditional on not expropriating other stakeholders in the firm. This version of shareholder value maximization is consistent with equilibrium, since all expectations of the firm's contracting parties are met. It is the target typically assumed in finance theory and the one that corporations would pursue in frictionless markets. If (a) securities are traded, (b) transaction costs are reasonably low, and (c) asymmetries of information between managers and investors are limited, then managers who do not maximize shareholder value create an 
incentive for investors to take over their firms and install new managers willing to maximize shareholder value (Manne, 1965). ${ }^{10}$

According to the table, the answers are similar regardless of whether the firms are traded. The only exception concerns the maximization of shareholder value. We will come back to that exception. Let us first focus on the answers of the full sample of firms. Almost all firms (96\%) want to maximize customer satisfaction (4\% state that they do not);11 a sizable fraction (81\%) wants to maximize stakeholder value (stakeholders include shareholders, employees, customers, and the environment); an equally sizable fraction (79\%) wants to maintain independence; and two thirds (68\%) intend to maximize profits. Moreover, more than half of the firms say they want to maximize shareholder value as long as this does not come at the expense of other stakeholders in the firm. ${ }^{12}$

We should note the fundamental difference between the notions of shareholder and stakeholder value maximization, as defined here, even if in either case there is a reference to firm stakeholders. In the case of shareholder value maximization, the implicit or explicit contracts with other stakeholders have to be met in the maximization attempt. These contracts, and therefore the interests of the involved stakeholders, represent maximization constraints. In contrast, in the case of stakeholder value maximization, the interests of these stakeholders are part of the target function itself. The problem with the latter target is that, since the interests of the various parties in the firm are competing, it is not clear how they can be maximized at the same time. All else being equal, for instance, lower prices make consumers better off and higher salaries benefit employees and managers, yet both reduce shareholder value. The stakeholder value maximization target is therefore a logical impossibility.

There are two things to stress about these answers. First, many firms pursue different, mostly conflicting targets at the same time. ${ }^{13}$ Second, there is no apparent

10 Shareholders are generally residual claimants because they can diversify risk more efficiently than other stakeholders in the firm.

11 We do not mean this literally. Organizations per se do not pursue goals. It is the individuals in those organizations who do.

12 The questionnaire also asked whether managers pursue shareholder value unconditionally. Less than one third $(28 \%)$ of the respondents gave an affirmative answer.

13 The finding of multiple targets is consistent with what companies say in their mission statements. These statements typically mention the importance, without providing any ranking, of the welfare of employees, customer satisfaction, shareholder wealth, and the environment. 
evidence that the public debate mentioned above puts pressure on managers to misstate their preference for shareholder value maximization. We consider these two issues in some detail in the following two subsections. Given the length of the discussion, we then summarize and interpret our findings in a third subsection.

\subsection{Pursuing multiple targets simultaneously}

Managers claim to pursue multiple targets simultaneously. For instance, they apparently maximize customer satisfaction, stakeholder value, and profits while at the same time striving to maintain independence. Since most of these targets are not positively and monotonically related, these preferences are logically inconsistent. The phenomenon of multiple objectives has been noted before (see, among others, Jensen, Wruck, and Barry, 1991, and Cools and van Praag, 2000). ${ }^{14}$ Table 2 documents how many targets any one firm allegedly pursues. In this calculation, we include all the targets reported in Table 1.

\section{((insert Table 2))}

According to the table, $95 \%$ of the firms pursue at least two targets, and $19 \%$ pursue all six targets. Since logical inconsistencies could be a characteristic of smaller, less sophisticated firms, we replicate the analysis for the sample of listed firms. We would expect listed firms to give more logical answers. Yet the numbers reveal essentially the same picture: $93 \%$ of the firms that are listed indicate at least two maximization targets, and $21 \%$ pursue all six targets at once. ${ }^{15}$

The logical inconsistency of simultaneously pursuing mutually exclusive targets is particularly evident when we restrict our attention to the targets of shareholder and

14 The targets examined in Cools and van Praag's survey of 80 large listed Dutch firms include: (1) financial accounting targets (e.g., net profit per share, ROA, or ROE); (2) financial value-based targets (e.g., shareholder value, or EVA); (3) growth-based targets; (4) operational targets (e.g., credit rating, or product quality); and (5) social targets (e.g., corporate governance, transparency, or social responsibility). In comparison, the targets we are interested in are mostly indications of what group of claimholders managers intend to benefit with their efforts. Moreover, we focus specifically on "maximization." Both aspects of our investigation make it easier to assess logical inconsistencies in what managers say and, possibly, do.

15 The inability to make more precise indications could be interpreted as measurement error for the "true" goal. If so, using these indications as independent variables in our subsequent regressions induces an attenuation bias in the slope coefficient estimates and reduces the statistical significance of those estimates. 
stakeholder value maximization. Maximization of stakeholder value, assuming this is possible, is inconsistent with maximization of shareholder value. Managers do not seem to realize this contradiction. As shown in the two-way contingency table reported in Table 3, 62\% $(=133 / 215)$ of the managers who claim to maximize stakeholder value also adhere to a policy of shareholder value maximization. In contrast, only $32 \%(=18 / 57)$ of the managers who do not maximize stakeholder value also claim to maximize shareholder value. Thus, it would seem that managers who disclose a preference for stakeholder value maximization also have a preference for shareholder value maximization. According to the $\chi^{2}$-test of independence reported in the table, the two classifications of firms are not independent with confidence better than 0.99 .

((insert Table 3))

\subsection{Managerial targets and political correctness}

As mentioned above, the second regularity to note about Table 1 is that there is no apparent evidence that considerations of political correctness induce managers to misrepresent their preference for the goal of shareholder value maximization. As pointed out in the introduction, the media often associate the notion of shareholder value maximization with greed. This standpoint could pressure managers to shy away from advocating the maximization of shareholder value. Yet we find little apparent evidence that this pressure, if any, is effective. There are two reasons to say so.

The first reason is that managers have no apparent qualms about saying that they maximize profits, a measure of the benefits shareholders reap in the firm. If managers were concerned about being politically correct, they would probably be reluctant to list profit maximization as a goal. In fact, about two thirds of the managers who fill out the questionnaire are willing to state that they do maximize profits. The second reason is that, if managers were concerned about being politically correct, we would expect those of listed firms to be more hesitant to disclose an intention to maximize shareholder value. The assumption, of course, is that these managers have the greatest political exposure - after all, they are the ones the media are more likely to cover. Yet, when we look at the sample of listed firms we observe, if anything, the opposite tendency. According to Table 1, listed firms are more likely to mention 
shareholder value maximization as their target. Specifically, $75 \%$ of the listed firms indicate shareholder value maximization, compared with $57 \%$ in the full sample. ${ }^{16}$ It could be that, since listed firms have cheaper access to the capital market for equity funding than unlisted firms, they face a stronger incentive to identify with the goal of shareholder value maximization. Still, it is difficult on the basis of these results to make the argument that managers fabricate their preference for shareholder value maximization for political convenience.

The relations we have seen so far are univariate. They could therefore be spurious. To find out, we reexamine the relevant relations in a multivariate context. The relations are tested with the help of logistic regressions. The dependent variable is bSHAREMAX, a binary variable equal to 1 if managers claim they maximize shareholder value, and equal to 0 otherwise. ${ }^{17}$ Table 4 reports the results. Its individual columns illustrate the regression coefficients for different samples or different regression specifications.

((insert Table 4))

Column (1) refers to the full sample. The first coefficient estimate refers to the variable bSTAKEMAX, a binary variable that identifies firms whose managers disclose a stakeholder value maximization target. The coefficient of bSTAKEMAX is positive and significant with confidence better than 0.99 . This means that shareholder value maximization is more likely if managers also say they maximize stakeholder value. We pointed out this logical inconsistency before, and it does not go away in a multivariate context. The results also show that the probability of shareholder value maximization is larger if the firm is listed (as measured by the binary variable bLISTED). This is in line with what we saw in Table 1. Firm size, however, as measured by the natural logarithm of the firm's employees (LNSIZE), has no impact on the propensity to maximize shareholder value.

16 There are also more managers who state a preference for unconditional shareholder value maximization in listed firms than in the full sample (40\% vs. 27\%). For simplicity, we do not expand on these results.

17 The letter $\langle\mathrm{b}\rangle$ in front of the respective acronym similarly identifies all binary variables in the following analysis. In all cases, the variable equals 1 if managers claim that something applies or if a certain condition occurs, and equals 0 otherwise. 
To interpret the coefficients in the table, let us examine the one associated with the variable bLISTED, which identifies listed firms. Its value of 0.849 means that if a firm is listed, the odds ratio that its managers will say they maximize shareholder value gets multiplied by $\exp (0.849)=2.34$. Consequently, suppose the probability of shareholder value maximization in otherwise identical but unlisted firms were 0.6 , for an odds ratio of $0.6 /(1-0.6)=1.5$. From our results, listed firms would have an average odds ratio of $1.5 \times 2.34=3.51$, meaning that the probability of shareholder value maximization in these firms would be about $0.78 . .^{18}$

Column (2) repeats the analysis for the listed firms. A quick look at the numbers shows that no variable except firm size has a significant coefficient. In particular, there is no relation between stakeholder and shareholder value maximization.

Column (3) extends the analysis with the inclusion of a binary variable (bCLOSELYHELD95), which measures the presence of a controlling shareholder in 1995. ${ }^{19}$ The coefficient associated with bCLOSELYHELD95 is positive and significantly different from zero, indicating that firms with a controlling shareholder are more likely to say they maximize shareholder value. This suggests that, at least in their statements, managers identify with the presumable interests of the controlling shareholder. Note also that with this specification, the coefficient of bSTAKEMAX becomes marginally significant in a one-sided test of significance.

Whether or not managers identify with the goal of shareholder value maximization depends on the incentives they face. Conceivably, if the company's stock price performance has been negative, they face more pressure to care about shareholder value and take corrective measures. Financial analysts and shareholders might otherwise ask embarrassing questions, or the firm might become an interesting takeover candidate. We therefore extend the analysis of column (3) and investigate the significance of past stock price performance, as measured by the change in the company's stock price. Specifically, we include the variable RETPOS among the regression arguments. RETPOS measures the company's stock return during the period January 1990-December 1995 if that return is positive; otherwise, RETPOS is

18 Denoting the probability of shareholder value maximization by $\pi$, the equation $\frac{\pi}{1-\pi}=3.51$ implies $\pi=0.78$.

19 The variable bSTAKEMAX was originally collected for the stock price performance analysis. That analysis covers the period 1.1996-12.2001, which is why the variable in question refers to 1995 and not to 1998 , the year of the survey. 
equal to 0 . Similarly, we include the variable RETNEG, which is similarly defined as RETPOS except for being equal to the negative stock return. When we estimate this specification, the sign and the statistical significance of the coefficients of the variables in the original specification in column (3) remain the same (not shown). As for the new variables, they appear to be significantly related to managers' preferences. The coefficient of RETPOS, for instance, is positive and significant with confidence better than 0.95 . All else being equal, larger stock price increases raise the odds of managers saying they maximize shareholder value. This could either reflect properly working corporate governance or an attempt on the part of managers to take credit for higher stock prices after the fact. More importantly, RETNEG has a negative, marginally significant coefficient with confidence 0.90 in a one-sided test of significance (not shown). The more negative the return, the stronger the identification with shareholder value maximization. The coefficients on the two variables RETPOS and RETNEG imply a v-shaped relation between stock returns and the likelihood that managers embrace shareholder value maximization.

Column (4) of the table exhibits the estimates of a slightly different specification than the one we just discussed, namely one in which we switch RETNEG with the dummy variable bRETNEG, which equals 1 if the company's stock return is negative during the five-year period January 1990-December 1995, and equals 0 otherwise. As one can see, all the variables reported in column (3) maintain their sign and significance. The statistical significance of the impact of negative returns on managers' preferences, however, increases when we measure them with the variable bRETNEG. Its coefficient is positive and significant with confidence better than 0.95 , consistent with the hypothesis that managers come under pressure to care about shareholder value when stock prices drop. The coefficient of RETPOS remains positive and significant. We can visualize the relation between managers' identification with shareholder value maximization and stock price changes with a horizontal line (with a positive intercept) as long as returns are negative, and an upward sloping straight line (through the intercept) when they are positive. It is not clear in what direction, if any, causality runs, particularly in the case of positive stock returns. But if we assume that returns affect managers' preferences, the relation we find is that a negative return has a constant impact on managers' preferences; in contrast, the impact of a positive return depends on the return's magnitude. When stock prices do not increase much, the incentive to embrace shareholder value 
maximization is much weaker than when they fall. As it turns out, prices have to increase by $58 \%(=2.989 / 5.120)$ for the effect of higher prices to equal that of lower prices (both changes measured over a five-year period).

Finally, column (5) duplicates the regression specification of column (2) for the unlisted firms. Again, the results confirm what we argued in connection with Table 3, namely that the logical inconsistency of trying to simultaneously maximize both shareholder and stakeholder value is driven mainly by the subsample of unlisted firms. The coefficient of the variable bSTAKEMAX is significant with confidence higher than 0.99 .

\subsection{Summary}

Overall, we find that, when asked about their targets, managers typically mention several contradictory goals. In unlisted firms, managers even profess to maximize both shareholder and stakeholder value at the same time (Table 4). We also uncover evidence that the identification with shareholder value maximization increases when stock prices fall. It is not clear why managers allegedly pursue multiple, conflicting targets. They may not understand the implications of what they say. Or, they may think that, by mentioning several targets, they can limit the embarrassment of saying something wrong. In either case, the answers reveal a fundamental insecurity and consequently an inability to set clear priorities. Of course, we may not have listed the relevant target in the question we asked, thus inducing people to cross the possibilities we presented. Yet we gave managers the choice of completing the list of possible targets. Several managers used this opportunity. Although several possibilities were listed, ${ }^{20}$ none was mentioned by more than $13 \%$ of the respondents. Thus there is little reason to believe that they were somehow trapped into giving the answers we received.

Yet another interpretation of why managers indicate multiple targets is that managers may misinterpret the term maximization. Maximization of customer satisfaction, for instance, may simply be taken to mean, "making sure that the customer is satisfied." Similarly, maximization of stakeholder value might be interpreted as "taking into account the interests of stakeholders." This latter

20 Managers indicated things such as securing the firm's survival, being an attractive employer, increasing customers' utility, and guaranteeing jobs. 
interpretation should probably be dismissed because, when asked whether they maximize shareholder value unconditionally, less than one third of the managers in the sample say they do (not shown in Table 1). In contrast, had they meant, "making sure the shareholders are satisfied," a large majority would probably have agreed. Still another possible interpretation of the results is that managers may lack the proper incentives to pursue any one particular target. This would suggest a malfunctioning corporate governance system.

One final reason why managers may pursue several (conflicting) targets at the same time could be managerial overconfidence. According to this hypothesis, managers are so self-confident that they think they can achieve the impossible. There are observations that overconfidence can lead to illogical statements. For example, a large majority of drivers think of themselves as above average drivers (Shefrin, 2001).

The tendency of managers to pursue different targets simultaneously complicates the interpretation in the following analysis. As mentioned in the introduction, we examine whether shareholder value maximizing managers make logically consistent decisions. We also investigate whether these managers actually create more shareholder value than other managers. The problem is that, given the tendency to pursue different targets at the same time, it is not clear what managers who state that they maximize shareholder value really do maximize. ${ }^{21} \mathrm{We}$ can, however, take their answers at face value when they say they do not pursue that target.

We also observe that a substantial number of managers, particularly in unlisted firms, are willing to go on record as not pursuing the target of shareholder value maximization. More than half of the firms that are not listed and almost one quarter of those that are come out and say so. This would seem to represent the paradoxical case of an agency relation in which the agent openly declares that he intends to make decisions that are not in the principal's interests.

Why do so many managers, particularly in unlisted firms, fail to identify with the goal of shareholder value maximization? One possibility is that they do not properly understand the issues involved and are confused by the many contradictory reports they receive from the media and some academics on the subject. Another, not exclusive possibility is that the notion of shareholder value might not mean much in

21 As it turns out, they also focus on the following targets: $99 \%$ of them want to maximize customer satisfaction; $82 \%$ aspire to maintain independence; $88 \%$ maximize stakeholder value; and $76 \%$ maximize profits. 
unlisted firms. These firms are generally closely held and very jealous of their independence. Short of selling their shares, the most obvious way owner-managers can dispose of the economic surplus they generate is to pay themselves higher incomes, dividends, and perks. The notion of shareholder value maximization might simply not be relevant.

A third possibility for why managers are willing to state they do not maximize shareholder value is that the control mechanisms to prevent them from straying too far from that target might not be working. In particular, there might be no effective pressure from the capital market to behave otherwise, particularly in the case of unlisted firms. The threat of takeover is the main mechanism outside the firm that keeps firms from diverging too much from a policy of shareholder value maximization. ${ }^{22}$ Yet, for this device to be effective, some assumptions have to be met. In particular, the firms' stock must be traded. That assumption, however, is compromised in the case of unlisted firms, which could explain our findings.

\section{How managers decide: The evidence}

In this section, we first examine the criteria managers rely on when making investment decisions and the approaches they adopt when valuing firms. ${ }^{23}$ Second, we look at whether firms that use an NPV investment criterion also use a DCF firmvaluation approach. Third, we investigate whether firms that maximize shareholder value also use the NPV and the DCF metrics. Finally, we summarize the results.

\subsection{Investment valuation criteria}

The questionnaire asks managers to indicate the criterion they ultimately rely on when deciding what projects to invest in. As it turns out, they mostly rely on payback and NPV (not shown). ${ }^{24}$ Almost all (about 80\%) employ payback regardless of whether or not they are listed. As for NPV, listed firms use it much more frequently

22 Mechanisms inside the firm include monitoring by the board of directors, appropriate compensation packages, and managerial equity participation.

23 The issue of actual investment efficiency is discussed separately in Jörg, Loderer, and Roth (2003).

24 They also depend on the internal rate of return (IRR) metric. We focus on payback and NPV because they represent the most divergent criteria. Additional information concerning the investment criteria and the firm valuation approaches employed in the sample firms is in Loderer, Jörg, Pichler, Roth, and Zgraggen (2002). 
than unlisted firms (the associated percentages are about 71\% for listed firms and $42 \%$ for firms that are not). ${ }^{25}$ Further differences become apparent when we sort the sample by project size.

The questionnaire does not provide a specific definition of project size. What constitutes small, medium, and large projects is in the eyes of the responding manager. Listed firms tend to rely comparatively more often on NPV and less often on payback than unlisted firms, particularly if the project is large. In particular, 38\% of the listed firms use payback in deciding about large projects, compared with $64 \%$ of the unlisted firms; for small projects, the corresponding proportions are $61 \%$ and $73 \%$. Similarly, $56 \%$ of the listed firms rely on NPV when investing in large projects, compared with $32 \%$ of the unlisted firms; for small projects, these proportions fall to $30 \%$ and $17 \%$.

These results make intuitive sense under a shareholder value maximization target. On the one hand, small projects can be decided on the basis of payback because it is easier to use and the costs of making wrong decisions are low. When projects are large, however, the costs of making mistakes grow larger, and we should observe a more frequent use of NPV. On the other hand, the fact that payback is less often the deciding criterion among listed firms than among unlisted ones could reflect greater financial sophistication in listed firms. Alternatively, it could reflect the greater difficulties in implementing the NPV criterion (in particular, the difficulties of measuring an appropriate discount rate) in unlisted firms.

Besides inquiring about investment criteria, the questionnaire looks into the approaches managers use to value companies. To limit space, we do not report the results in a separate table. The most popular approach among listed firms is the DCF approach; almost $90 \%$ of them use it. In contrast, the approach preferred by unlisted firms is the earnings value method, an approach that computes equity value as the present value of a perpetual stream of sustainable future earnings; almost $86 \%$ of the unlisted firms use this method. Firms also use other methods, including valuing firms by aggregating the value of their individual assets: about $55 \%$ of the unlisted firms and $38 \%$ of the listed firms use this method.

25 In a survey of CFOs of listed American firms, Graham and Harvey (2001) find that large firms are significantly more likely to use NPV techniques than small firms. They are also significantly less likely to use payback. 


\subsection{Relation among valuation criteria}

Having examined the metrics used to value investment projects, we now want to ask whether the firms that use the NPV investment criterion also value firms with a DCF approach. The two techniques follow the same logic, which is why we expect a correlation. Table 5 answers the question in a multivariate context with a logistic regression. The dependent variables are binary. The variable (bNPV) gauges whether firms use the NPV criterion, whereas the variable (bNPVLARGE) indicates whether NPV is the deciding criterion for large projects. Numbers in parentheses are probability values for two-sided tests of difference from zero. ${ }^{26}$ The economic interpretation of the estimated coefficients is similar in principle to that discussed in the context of Table 4. In other words, an increase in the variable in question by one unit multiplies the odds ratio that firms use NPV as an investment criterion by an amount equal to the constant e raised to the power of the variable's coefficient.

((insert Table 5))

Column (1) shows that the likelihood of NPV adoption increases if the firm is listed (variable bLISTED) and if it is large (variable LNSIZE). More importantly, the results indicate that firms using a DCF firm valuation approach (as identified by the variable bDCFVALUATION) are more likely to use the NPV investment criterion. Moreover, the variable bASSETVALUATION has a negative coefficient, which indicates that companies that value other firms with the aggregate value of their individual assets (as indicated by the variable bASSETVALUATION) are less likely to use NPV. This result is intuitive, since this firm valuation approach is logically inconsistent with the NPV approach. All these relations are significant with confidence better than 0.95 in a two-sided test of difference from zero; the exception is the coefficient of the variable bLISTED, which is significant with 0.91 confidence. The table includes coefficient estimates for two other arguments, bSTAKEMAX and bSHAREMAX, which we will discuss in the next section.

Column (2) of the table repeats the regression in column (1) for the sample of unlisted firms. The main message of column (1) remains unaltered: firms that adopt a

26 In some cases, one-sided tests would be more appropriate. Still, we do not always have clear predictions for the sign of the various regression coefficients. To avoid confusion, we therefore always perform two-sided tests of statistical significance. 
DCF valuation approach are more likely to also use NPV, whereas firms that rely on asset value are less likely to do so. Both relations are statistically significant with confidence close to 0.95 . The coefficient of firm size, however, is not significant.

Column (3) reports the results for the listed firms. The coefficient estimates show that, contrary to what we observe in the full sample, there is no inverse relation between the use of asset value in firm valuation (bASSETVALUATION) and the use of NPV in listed firms. The coefficients of the variables bDCFVALUATION and LNSIZE, however, remain significant with confidence of at least 0.90 . The finding concerning the variable bDCFVALUATION should not be overemphasized, however. Almost $90 \%$ of the firms that are listed use DCF to value firms. Thus, there is little variation in the variable in question to perform a robust test of the relation between the DCF approach and the NPV criterion in listed firms.

We replicated the analysis by focusing on the use of NPV for large projects. The rationale is that, as discussed above, NPV is used more often for large projects, possibly because wrong decisions on these projects have more serious consequences for the firm. We therefore wanted to see whether the same results obtain when focusing on situations in which the use of NPV has an unambiguous economic justification. The results (not shown) are qualitatively unchanged.

\subsection{Valuation criteria and shareholder value maximization}

The preceding sections have uncovered a fairly strong relation between the use of the NPV investment criterion and the DCF approach to firm valuation. Since both methods compute value by discounting expected future cash flows, this relation makes logical sense. As explained in Section 2.2, it makes also economic sense if the firm's target is shareholder value maximization. Whether in fact there is a positive tie between NPV and DCF on the one hand and shareholder value maximization on the other is the issue we investigate now.

First, let us explore the existence of a relation between shareholder value maximization and the use of NPV. The necessary evidence is reported in the table we have just discussed (Table 5). Column (1) shows that the coefficient of the variable bSHAREMAX, which identifies the firms that claim to maximize shareholder value, is insignificantly different from zero. Hence in the full sample there is no relation between the goal of shareholder value maximization and the use of NPV. This 
finding is at odds with what we would expect, since NPV gives managers a measure of value added that is relevant in the quest for higher shareholder value. There is no relation either between the goal of stakeholder value maximization (as indicated by the variable bSTAKEMAX) and the use of NPV. This finding is more in line with our expectations, since there is no logical reason why firms that claim to maximize stakeholder value would rely on NPV. The stakeholder value maximization target has no obvious operational interpretation and is therefore consistent with any metric used to decide on firm acquisitions or sales.

The finding of no relation between adherence to a shareholder or stakeholder value maximization target and NPV use does not depend on whether the firm is listed. We can tell so by examining columns (2) and (3) of the table. In neither column are the coefficients of the two variables bSHAREMAX and bSTAKEMAX significant at customary levels of confidence. The same conclusion follows when we replicate the regressions in Table 5 by focusing on the use of NPV in large projects (not shown).

In Table 6, we examine the relation between the targets of shareholder and stakeholder value maximization with the DCF firm value metric. We do so within a logistic regression framework similar in spirit to that used in Table 5. The dependent variable is the use of DCF in firm valuation, whereas the independent variables include whether the firm uses NPV, whether it is listed, its size, and whether it maximizes shareholder or stakeholder value.

((insert Table 6))

Column (1) refers to the full sample. Firms that use NPV are also more likely to use a DCF firm-valuation approach. The column also shows that the odds of a firm using a DCF valuation approach increase if the firm is listed - the coefficient of bLISTED is positive and significant with confidence better than 0.95 . This could be because the DCF valuation approach is easier to implement for listed companies, and because listed companies are more likely to be acquisition targets of listed firms than of unlisted ones. The positive and marginally significant coefficient reported for firm size (LNSIZE) would seem to have a similar interpretation. Large firms are more likely to use DCF because they are more likely to acquire listed firms.

The remaining two regression coefficients reported in column (1) are the ones of most relevance here. The one associated with shareholder value maximization 
(bSHAREMAX) is positive and marginally significant with 0.90 confidence in a onesided test against zero. The implication is that shareholder value maximizing firms are more likely to use DCF valuation. As mentioned before, this is what one would expect, since DCF helps identify acquisition and sale opportunities that add to shareholder value. The second coefficient is associated with the variable bSTAKEMAX and is negative and statistically significant with 0.99 confidence. Accordingly, firms that claim to maximize stakeholder value are significantly less likely to use a DCF valuation approach. There is no reason for managers to be concerned about value added if they pursue a target of stakeholder value maximization.

Column (2) of the table duplicates the estimation for the unlisted firms. The results are very similar to those obtained for the full sample. In particular, shareholder value maximization increases the odds that the firm uses DCF valuation, whereas stakeholder value maximization has the opposite effect. The only difference between the two columns is that the coefficient estimates in column (2) are statistically almost uniformly more significant than those in column (1). Column (3) then restricts its focus to the subsample of listed firms. With the exception of the use of NPV, no regression argument is statistically significant with 0.90 confidence in either a one-sided or a two-sided test against zero. Especially, there is no relation between the adoption of the shareholder value maximization target and DCF

valuation. This result is rather puzzling. One possible explanation is that, since $80 \%$ of the listed firms claim to maximize both shareholder and stakeholder value, there are not enough sample firms that maximize only one or the other to perform a clean test of the relevance of these targets.

\subsection{Summary}

Overall, this section finds that firms make logical investment decisions. If they use the NPV criterion, they also tend to use a DCF firm-valuation approach. At the same time, they refrain from valuing firms as if they were in liquidation. These methods, however, are not consistently related to the target of shareholder value maximization. Specifically, firms that claim to maximize shareholder value do not rely more often on NPV than other firms. They do, however, tend to use a DCF firm- 
valuation approach more often than other firms. In contrast, firms that claim to maximize stakeholder value are less likely to use a DCF firm-valuation approach.

\section{What managers do: The evidence}

The last question we want to answer is in many respects the most interesting: namely, what managers really do and how that relates to what they say. As pointed out in section 2.3, firm performance is measured with abnormal stock returns. For obvious reasons, the analysis can therefore be carried out only for the listed firms in the sample. This is true of alternative measures of performance, including ROE and market-to-book ratios. Since the sample of traded firms is rather limited, the results are mostly suggestive.

We computed the abnormal stock price performance of these firms between January 1996 and December 2001 with the monthly intercept $\alpha_{i}$ in the regression equation (1), cumulated over the 72 months of the period in question. ${ }^{27}$ On average, the sample firms lose about $16 \%$ of their stock price conditional on their systematic risk. The cross-sectional variation in performance is sizable. Firms in the bottom quartile of the distribution lose $62 \%$, whereas firms in the top quartile experience an appreciation of $34 \%$. In what follows, we ask whether that variation depends on whether or not managers pursue a target of shareholder value maximization and on the methods they use. We carry out the investigation with a robust regression of abnormal stock-price performance against possible determinants. The results are shown in column (1) of Table 7.28

((Insert Table 7))

Accordingly, firms that allegedly pursue a shareholder value maximization policy perform systematically better than others; the coefficient of bSHAREMAX is statistically greater than zero with confidence of about 0.95 in a one-sided

27 Only 58 firms were listed from the beginning of the period under analysis. This explains why the number of observations is smaller than the number of listed firms (75) in the sample. No firm in the sample was taken over, went bankrupt, or was otherwise delisted during the years in question.

28 There are 58 listed companies with sufficient stock return data, but not all of them answered the relevant questions. This explains why the number of observations differs across regression specifications. 
significance test (as before, the table shows probability values for two-sided tests only). A look back at what we learned about the targets managers pursue helps us calibrate this statement. Given that managers pursue several targets at the same time, it is not clear what they really do when they say they maximize shareholder value. If we take their statements at face value, however, we know what they do when they say they do not maximize shareholder value. The positive coefficient of bSHAREMAX can therefore be interpreted as meaning that, when managers say they do not maximize shareholder value, stock-price performance is indeed significantly worse than otherwise.

The results in column (1) also include a coefficient for the variable bDCFVALUATION that is positive and significant with better than 0.95 confidence. This suggests that firms that rely on a DCF firm-valuation approach perform better than others. Given this result, it is rather surprising that the use of NPV in the valuation of large projects does not contribute to higher share prices; the coefficient of bNPVLARGE is not significant at customary levels of confidence. We reach the same conclusion if we replace bNPVLARGE with bNPV, a binary variable that characterizes firms whose managers claim to use NPV as an investment criterion. The significant coefficient of bDCFVALUATION should once again be interpreted with caution, since the cross-sectional variation of this variable is small.

The regression arguments also include a variable (CLOSELYHELD95) that measures the presence of a shareholder with more than $50 \%$ of the votes in 1995 , and a variable (OWNERSHIPCHANGE) that measures the change in the holdings of that particular shareholder between 1990 and 1995. The rationale for the inclusion of CLOSELYHELD95 is that a controlling shareholder has the financial incentive and the ability to influence managerial decisions. The rationale for the inclusion of OWNERSHIPCHANGE is that a change in the controlling shareholder's stakes might reflect an increased willingness to influence managerial decisions.

These variables are included to prevent an omitted-variable bias. The results suggest that the presence of a controlling shareholder has no direct bearing on performance (the coefficient of CLOSELYHELD95 is not significantly different from zero at customary levels of confidence). There might be, however, an indirect influence. As one might remember from Table 4, the presence of a controlling shareholder appears to tilt managers' preferences toward the goal of shareholder value maximization. And, as we have just seen, managers who disclose that preference 
appear to perform marginally better than others. Thus a controlling shareholder may affect performance because his presence induces managers to maximize shareholder value. Other than this indirect effect, there is not much, according to the evidence, that a controlling shareholder adds to firm performance. We are lumping all controlling shareholders together, however, without trying to distinguish individual investors from corporate shareholders, family holdings from other holdings, etc. The limited number of observations in the sample discourages such distinctions. Still, when we use the variable OWNERSHIPCHANGE to look at cases in which the holdings of the controlling shareholder have recently changed, we find a positive and significant relation between the size of that change and performance. The question, of course, is the direction of causality. Does the controlling shareholder's increased investment induce better performance, or does anticipated better performance encourage larger stockholdings?

In column (2), we replicate the regression by investigating the importance of the method used to measure firm value. We do this by replacing the variable bDCFVALUATION with the variable bASSETVALUATION, which, as we have discussed above, identifies firms that assess firm value by adding up the value of a company's individual assets. All the other variables remain the same as in column (1). As one can see, this specification has substantially less explanatory power than the preceding one: the adjusted $\mathrm{R}^{2}$ falls from $16 \%$ to $6 \%$. Moreover, the coefficient of bASSETVALUATION is not significant at customary levels of significance.

Overall, the results uncover a weak relation between performance and pursuit of a policy of shareholder value maximization. The pursuit of other targets, such as maximization of stakeholder value, firm profits, or customer satisfaction, has no apparent impact on performance (not shown). We also observe that the methods used to implement a policy of shareholder value maximization can affect performance. The use of DCF to value firms, for instance, is associated with better performance. The use of NPV, however, is not.

In Table 4, we observed that managers are more likely to identify with the goal of shareholder value maximization if their companies' share prices have declined. The rationale is that when stock prices drop there is more pressure to make decisions that benefit shareholders. If we extend that logic, we would expect that the combination of share price declines and subsequent statements by managers that they want to maximize shareholder value should be associated with better stock price 
performance - the implicit assumption being that investors do not perfectly anticipate managers' reaction.

To test this hypothesis, we replicate the regression specification in column (1) with the addition of two variables. The first variable, bSHAREMAX*RETNEG, is a binary variable equal to 1 if managers say they maximize shareholder value and the company's stock price has declined during the period January 1990-December 1995; otherwise, the variable equals 0 . The second variable, bSHAREMAX*RETPOS is similarly defined except for focusing on firms whose stock prices have increased rather than decreased. The results are shown in column (3) of Table 7. To avoid clutter, we omit the independent variable CLOSELYHELD since it has an insignificant coefficient.

To interpret the results, note that, if we include the two new variables in the regression, we have to omit the variable bSHAREMAX, since it is a linear combination of the two. This replacement partitions the sample of firms that claim to maximize shareholder value into those whose stock prices have fallen and those whose stock prices have gone up. The new specification therefore enables us to interpret the weak relation between shareholder value maximization and abnormal stock price performance we just found. A look at the new results in column (3) reveals that, with the obvious exception of the coefficients of bSHAREMAX*RETNEG and bSHAREMAX*RETPOS, the remaining coefficients are essentially the same as those reported in column (1) of the table. Let us therefore focus on the coefficients of the new variables. The coefficient of bSHAREMAX*RETNEG is positive and marginally significant with confidence 0.90 in a one-sided test of difference from zero. In contrast, the coefficient of bSHAREMAX*POS is statistically zero. It is therefore the firms that have experienced a stock price decline in the past that drive the relation between shareholder value maximization and performance. These firms appear to engage in activities that are beneficial to shareholders. The remaining firms seem to conform to investors' expectations and their activities do not cause abnormal returns. Given the sample size (41), the weight of this evidence should not be overemphasized. Additional research is necessary to substantiate our conclusions. 


\section{Conclusions}

The purpose of this paper is to examine whether managers maximize shareholder value. The investigation falls into three parts. First, we ask managers to disclose what goals they pursue. Generally, they are trying to reach many conflicting goals simultaneously, and shareholder value maximization is frequently and deliberately not one of them. There is also some evidence that managers of firms whose stock prices have fallen face increased pressure to care about shareholder value.

Second, we examine some of the tools managers adopt to reach their goals. Our results show that the use of NPV correlates positively with the use of DCF. However, whereas managers who rely on DCF also typically maximize shareholder value, we do not observe a similar relation with the use of NPV.

Third, we study whether abnormal stock-price performance is better in firms that want to maximize shareholder value and use the proper tools to do so. It should be stressed, however, that our sample is limited. More data are required to buttress our conclusions. According to our results, the firms of managers who want to maximize shareholder value achieve marginally better stock-price performance than other firms, particularly in firms whose share prices have fallen. Yet the evidence about the relation between the adoption of the proper decision criteria and performance is mixed. The use of DCF in firm valuation is associated with better abnormal stockprice performance. We find no such relation, however, for the use of NPV in project valuation.

What can be learned from these results? The first lesson is that pursuing the target of shareholder value maximization, and using the appropriate tools to do so, can indeed increase shareholder value. The second lesson is that managers appear to choose inconsistent targets because they are overconfident, lack the appropriate incentives to do otherwise, or fail to understand the inconsistencies. This could mean they also follow illogical policies. The inability to see that, for instance, profits and stakeholder value cannot be maximized at the same time as shareholder value, suggests that managers (particularly those of unlisted firms) are unable to see clearly the consequences of alternative courses of action. By implication, one has to wonder about the policies these managers implement. Of course, this conclusion rests on the assumption that managers understand the questionnaire and are willing to provide truthful answers. 
The third lesson to draw is that managers appear to be more willing to relate to the goal of shareholder value maximization when stock prices drop. This could suggest the presence of an incentive asymmetry. When stock prices fall, it may be easier for critics to argue that serious mistakes have been committed and to ask for corrective action. It is also possible that caring for shareholder value is politically more acceptable when shareholders have lost than when they have made money.

The fourth lesson we can learn is that many managers (about half in the total sample and $25 \%$ in the sample of listed firms) are willing to state for the record that they intend to follow policies not necessarily in the interests of shareholders. In some unlisted firms, this might simply show that the controlling manager extracts his rents through higher salaries or various perks rather than through cash payouts to all shareholders (there could be tax reasons for doing so). Still, in many cases this attitude could reveal managers' confidence that shareholders do not want or are unable to force them to behave otherwise, something that could occur because of the absence of the appropriate controls or of the appropriate legal or judicial framework.

This managerial attitude could have several theoretical and practical implications. Among the theoretical implications would be that the standard principal-agent models of the corporation, with shareholders in the role of principals, yield inadequate representations of reality. There might be as many competing principals as there are stakeholders in the firm (see also Becht, Bolton, and Röell, 2002, and the literature cited therein), and no rule to rank or aggregate their preferences. One practical implication is that it would be difficult to hold managers accountable for their decisions, since, in the absence of a single-valued objective function and with no criteria for resolving tradeoffs among the corporation's goals, it is not clear what managers should and should not do (Jensen, 2001).

Yet another practical implication is that firms whose managers claim to maximize shareholder value experience somewhat better share-price performance. This seems to occur because managers react to stock price declines with corrective actions. Actual performance therefore appears to correspond to intentions. Whether, as many critics maintain, that occurs at the expense of other stakeholders in the firm is currently under investigation in a separate research project. 


\section{References}

Becht, M., Bolton, P., and A. Röell, 2002. Corporate governance and control. In: Constantinides, G., Harris, M., Stulz, R. (Eds.), The Handbook of the Economics of Finance. Elsevier Science, forthcoming.

Benelli, G., Loderer, C., Lys, T., 1987. Labor participation in private business policymaking decisions: West Germany's experience with codetermination. Journal of Business 60, 553-575.

Berle, A.A., 1931. Corporate powers as powers in trust. Harvard Law Review 44, 1049-1074.

Brennan, M.J., 2001. Corporate investment policy. In: Constantinides, G., Harris, M., Stulz, R. (Eds.), The Handbook of the Economics of Finance. Elsevier Science, forthcoming.

Cools, K., van Praag, M., 2000. The value relevance of a single-valued corporate target: An empirical analysis. Unpublished working paper. Department of Economics, University of Amsterdam, Amsterdam.

Dodd, M., 1932. For whom are corporate managers trustees?. Harvard Law Review $45,1145-1148$.

Freeman, R.E., 1984. Strategic management: A stakeholder approach. Pitman, Boston.

Graham, J.R., Harvey, C.R., 2001. The theory and practice of corporate finance: Evidence from the field. Journal of Financial Economics 61, 187-243.

Jensen, M.C., 2001. Value maximization, stakeholder theory, and the corporate objective function. European Financial Management 7, 297-317.

Jensen, M.C., Meckling, W.H., 1976. Theory of the firm: Managerial behavior, agency costs and ownership structure. Journal of Financial Economics 3, 305-360.

Jensen, M.C., Wruck, K.H., Barry, B., 1991. Fighton, Inc. (A) and (B). Harvard Business School Case \#9-391-056.

Jörg, P., Loderer, C.F., Roth, L., 2003. Socialism and intrafirm asset allocation, Unpublished working Paper. Institut für Finanzmanagement, Universität Bern, Bern.

Loderer, C.F., Jörg, P., Pichler, K., Zgraggen, P., 2002. Handbuch der Bewertung. Verlag Neue Zürcher Zeitung, Zürich.

Manne, H.G., 1965. Mergers and the market for corporate control. Journal of Political Economy 73, 110-120.

Myers, S.C., 1977. Determinants of corporate borrowing. Journal of Financial Economics 5, 146-175. 
N.N., 2002. Corporate social responsibility, lots of it about. The Economist, Dec. 12, 2002, http://www.economist.com/displayStory.cfm?Story_ID=1491618.

Shefrin, H., 2003. Behavioral corporate finance. Journal of Applied Corporate Finance, forthcoming.

Stout, L.A., 2002. Bad and not-so-bad arguments for shareholder primacy, Southern California Law Review 75, 1189-1210.

Wagner, F.W., 1997. Shareholder value: Eine neue Runde im Konflikt zwischen Kapitalmarkt und Unternehmensinteresse. Betriebswirtschaftliche Forschung und Praxis 49, 473-498. 


\section{Tables}

\section{Table 1}

Managerial targets

The table reports the frequency with which managers claim to pursue a given target. Numbers in parentheses refer to the number of firms willing to state an opinion. For instance, 68 listed firms have disclosed their opinion concerning maximization of customer satisfaction, and $94.1 \%$ of these firms say they actually pursue that particular target. The sample year is 1998 .

\begin{tabular}{lccc}
\hline & All Firms & Listed Firms & $\begin{array}{c}\text { Answers provided } \\
\text { by the CFOs, } \\
\text { Treasurers, and } \\
\text { Controllers }\end{array}$ \\
\hline $\begin{array}{l}\text { Maximization of customer } \\
\text { satisfaction }\end{array}$ & $95.9 \%$ & $94.1 \%$ & $96.2 \%$ \\
$\begin{array}{l}\text { Maximization of stakeholder } \\
\text { (shareholders, employees, }\end{array}$ & $(295)$ & $(68)$ & $(210)$ \\
customers, environment, etc.) value & $(294)$ & $87.7 \%$ & $80.9 \%$ \\
Maintaining independence & $78.7 \%$ & $(65)$ & $(209)$ \\
Profit maximization & $(291)$ & $79.7 \%$ & $75.7 \%$ \\
Maximization of shareholder value & $68.2 \%$ & $(64)$ & $(206)$ \\
without expropriating other & $(286)$ & $71.0 \%$ & $69.8 \%$ \\
stakeholders & $57.0 \%$ & $(69)$ & $(202)$ \\
Maximization of market share & $(284)$ & $75.0 \%$ & $58.9 \%$ \\
& $55.5 \%$ & $(64)$ & $(197)$ \\
& $(281)$ & $48.4 \%$ & $56.1 \%$ \\
\hline
\end{tabular}

Table 2

Number of maximization targets allegedly pursued by any one firm

The table shows the percentage of answering firms that pursue a given number of targets. The targets in question are those reported in Table 1. The sample year is 1998.

\begin{tabular}{ccc}
\hline Number of maximization targets & $\begin{array}{c}\text { Full sample of answering firms } \\
(313)\end{array}$ & $\begin{array}{c}\text { Listed answering firms } \\
(75)\end{array}$ \\
\hline 0 or more & $100.0 \%$ & $100.0 \%$ \\
1 or more & $99.0 \%$ & $98.7 \%$ \\
2 or more & $95.2 \%$ & $93.3 \%$ \\
3 or more & $85.3 \%$ & $82.7 \%$ \\
4 or more & $64.9 \%$ & $65.3 \%$ \\
5 or more & $40.3 \%$ & $38.7 \%$ \\
6 & $18.5 \%$ & $21.3 \%$ \\
\hline
\end{tabular}




\section{Table 3}

Shareholder vs. stakeholder value maximization

The table reports the frequencies with which managers pursue two targets: shareholder and stakeholder value maximization. The sample year is 1998 .

\begin{tabular}{|c|c|c|c|c|}
\hline & & \multicolumn{2}{|c|}{$\begin{array}{l}\text { We maximize stakeholder (shareholder, } \\
\text { employee, customer, environment, etc.) value }\end{array}$} & \multirow[t]{2}{*}{ Total } \\
\hline & & yes & no & \\
\hline \multirow{2}{*}{$\begin{array}{l}\text { We maximize } \\
\text { shareholder value }\end{array}$} & yes & 133 & 18 & 151 \\
\hline & no & 82 & 39 & 121 \\
\hline Total & & 215 & 57 & 272 \\
\hline Pearson $\chi^{2}$ & & $16.729(0.000)$ & & \\
\hline
\end{tabular}




\section{Table 4}

Relation between shareholder value and stakeholder value maximization targets

The table examines the relation between the target of shareholder value maximization and that of stakeholder value maximization, using the 1998 survey as a basis. The investigation is performed with a logistic regression. The dependent variable is a dummy variable, bSHAREMAX, equal to 1 if managers say they maximize shareholder value, and equal to 0 if they do not say so. Each column reports the estimated regression coefficients for one particular specification and (in parentheses) the associated p-value for a two-sided test of difference from zero.

\begin{tabular}{|c|c|c|c|c|c|}
\hline \multirow[b]{2}{*}{ Independent variables } & \multicolumn{5}{|c|}{$\begin{array}{c}\text { Logistic regression coefficients } \\
\text { Dependent variable: } b S H A R E M A X\end{array}$} \\
\hline & $\begin{array}{l}\text { All firms } \\
\text { (1) }\end{array}$ & $\begin{array}{l}\text { Listed firms } \\
\text { (2) }\end{array}$ & $\begin{array}{l}\text { Listed firms } \\
\text { (3) }\end{array}$ & $\begin{array}{l}\text { Listed firms } \\
\text { (4) }\end{array}$ & $\begin{array}{l}\text { Unlisted } \\
\text { firms } \\
\text { (5) }\end{array}$ \\
\hline Constant & $\begin{array}{l}-1.085 \\
(0.058)\end{array}$ & $\begin{array}{l}-2.796 \\
(0.130)\end{array}$ & $\begin{array}{l}-5.637 \\
(0.021)\end{array}$ & $\begin{array}{c}-12.419 \\
(0.008)\end{array}$ & $\begin{array}{l}-0.724 \\
(0.251)\end{array}$ \\
\hline bSTAKEMAX & $\begin{array}{c}1.217 \\
(0.000)\end{array}$ & $\begin{array}{c}0.518 \\
(0.528)\end{array}$ & $\begin{array}{c}2.080 \\
(0.100)\end{array}$ & $\begin{array}{c}2.909 \\
(0.119)\end{array}$ & $\begin{array}{c}1.354 \\
(0.000)\end{array}$ \\
\hline bLISTED & $\begin{array}{c}0.849 \\
(0.026)\end{array}$ & & & & \\
\hline LNSIZE & $\begin{array}{c}0.033 \\
(0.729)\end{array}$ & $\begin{array}{c}0.490 \\
(0.052)\end{array}$ & $\begin{array}{c}0.621 \\
(0.025)\end{array}$ & $\begin{array}{c}0.982 \\
(0.034)\end{array}$ & $\begin{array}{l}-0.057 \\
(0.587)\end{array}$ \\
\hline bCLOSELYHELD95 & & & $\begin{array}{c}2.619 \\
(0.030)\end{array}$ & $\begin{array}{c}4.370 \\
(0.033)\end{array}$ & \\
\hline bRETNEG & & & & $\begin{array}{l}2.989 \\
(0.034)\end{array}$ & \\
\hline RETPOS & & & & $\begin{array}{c}5.120 \\
(0.020)\end{array}$ & \\
\hline Cox \& Snell R ${ }^{2}$ & 0.088 & 0.082 & 0.195 & 0.376 & 0.072 \\
\hline $\begin{array}{l}\text { Overall percentage of } \\
\text { correctly predicted } \\
\text { cases }\end{array}$ & $64.4 \%$ & $75.0 \%$ & $73.2 \%$ & $68.3 \%$ & $61.7 \%$ \\
\hline $\begin{array}{l}\text { Number of } \\
\text { observations }\end{array}$ & 270 & 56 & 56 & 41 & 214 \\
\hline \multicolumn{6}{|l|}{ Variable Definitions } \\
\hline bSTAKEMAX & \multicolumn{5}{|c|}{$\begin{array}{l}\text { Binary variable equal to } 1 \text { if the firm's management says it wants to } \\
\text { maximize stakeholders' value, and equal to } 0 \text { otherwise. Stakeholders } \\
\text { include shareholders, employees, customers, and the environment; }\end{array}$} \\
\hline bLISTED & \multicolumn{5}{|c|}{$\begin{array}{l}\text { Binary variable equal to } 1 \text { if the firm is listed on the Swiss Stock } \\
\text { Exchange, and equal to } 0 \text { otherwise; }\end{array}$} \\
\hline LNSIZE & \multicolumn{5}{|c|}{$\begin{array}{l}\text { Natural logarithm of firm size, measured by the number of firm } \\
\text { employees; }\end{array}$} \\
\hline bCLOSELYHELD95 & \multicolumn{5}{|c|}{$\begin{array}{l}\text { Binary variable equal to } 1 \text { if the firm has a shareholder with more than } \\
50 \% \text { of the votes in } 1995 \text {, and equal to } 0 \text { otherwise; }\end{array}$} \\
\hline bRETNEG & \multicolumn{5}{|c|}{$\begin{array}{l}\text { Binary variable equal to } 1 \text { if the company's stock return is negative } \\
\text { during January } 1990 \text {-December } 1995 \text {, and equal to } 0 \text { otherwise; }\end{array}$} \\
\hline RETPOS & \multicolumn{5}{|c|}{$\begin{array}{l}\text { Variable equal to the company's stock return during } \\
\text { January } 1990 \text {-December } 1995 \text { if that return is positive; otherwise, the } \\
\text { variable is equal to } 0 .\end{array}$} \\
\hline
\end{tabular}




\section{Table 5}

Relation between project valuation criteria and firm valuation approaches

The table examines the relation between project valuation criteria and firm valuation approaches. The analysis is based on the survey of 1998 and is performed with a logistic regression. Each column reports the estimated regression coefficients for one particular specification and (in parentheses) the associated p-value for a two-sided test of difference from zero. The dependent variable is bNPV, a dummy variable equal to 1 if managers claim to use NPV when making investment decisions, and equal to 0 otherwise.

\begin{tabular}{|c|c|c|c|}
\hline \multirow[t]{2}{*}{ Independent variables } & \multicolumn{3}{|c|}{$\begin{array}{c}\text { Logistic regression coefficients } \\
\text { Dependent variable: } b N P V\end{array}$} \\
\hline & $\begin{array}{l}\text { All firms } \\
\text { (1) }\end{array}$ & $\begin{array}{l}\text { Unlisted firms } \\
\text { (2) }\end{array}$ & $\begin{array}{c}\text { Listed firms } \\
\text { (3) }\end{array}$ \\
\hline Constant & $\begin{array}{l}-1.943 \\
(0.010)\end{array}$ & $\begin{array}{l}-1.487 \\
(0.069)\end{array}$ & $\begin{array}{l}-4.738 \\
(0.066)\end{array}$ \\
\hline bASSETVALUATION & $\begin{array}{l}-0.723 \\
(0.015)\end{array}$ & $\begin{array}{l}-0.849 \\
(0.009)\end{array}$ & $\begin{array}{c}0.059 \\
(0.942)\end{array}$ \\
\hline bDCFVALUATION & $\begin{array}{c}0.815 \\
(0.012)\end{array}$ & $\begin{array}{c}0.666 \\
(0.053)\end{array}$ & $\begin{array}{c}1.921 \\
(0.057)\end{array}$ \\
\hline bLISTED & $\begin{array}{c}0.751 \\
(0.087)\end{array}$ & & \\
\hline LNSIZE & $\begin{array}{c}0.223 \\
(0.050)\end{array}$ & $\begin{array}{c}0.169 \\
(0.179)\end{array}$ & $\begin{array}{c}0.550 \\
(0.094)\end{array}$ \\
\hline bSHAREMAX & $\begin{array}{l}-0.124 \\
(0.688)\end{array}$ & $\begin{array}{l}-0.163 \\
(0.627)\end{array}$ & $\begin{array}{c}0.219 \\
(0.802)\end{array}$ \\
\hline bSTAKEMAX & $\begin{array}{c}0.556 \\
(0.158)\end{array}$ & $\begin{array}{c}0.559 \\
(0.194)\end{array}$ & $\begin{array}{c}0.434 \\
(0.670)\end{array}$ \\
\hline Cox \& Snell $\mathrm{R}^{2}$ & 0.142 & 0.088 & 0.176 \\
\hline $\begin{array}{l}\text { Overall percentage of correctly } \\
\text { predicted cases }\end{array}$ & $67.1 \%$ & $65.5 \%$ & $78.6 \%$ \\
\hline Number of observations & 213 & 171 & 42 \\
\hline
\end{tabular}

\begin{tabular}{ll}
\hline Variable Definitions & $\begin{array}{l}\text { Binary variable equal to } 1 \text { if management claims to use NPV when } \\
\text { making investment decisions, and equal to 0 otherwise; }\end{array}$ \\
\hline bNPV & $\begin{array}{l}\text { Binary variable equal to } 1 \text { if managers say they value firms by looking at } \\
\text { the value of their individual assets, and equal to 0 otherwise; }\end{array}$ \\
bDCFVALUATION & $\begin{array}{l}\text { Binary variable equal to } 1 \text { if management says they value firms with a } \\
\text { DCF approach, equal to } 0 \text { otherwise; }\end{array}$ \\
bLISTED & $\begin{array}{l}\text { Binary variable equal to } 1 \text { if the firm is listed on the Swiss stock } \\
\text { exchange, and equal to } 0 \text { otherwise; }\end{array}$ \\
LNSIZE & $\begin{array}{l}\text { Natural logarithm of firm size, measured by the number of firm } \\
\text { employees; }\end{array}$ \\
bSHAREMAX & $\begin{array}{l}\text { Binary variable equal to } 1 \text { if the firm's management says it wants to } \\
\text { maximize shareholder value, and equal to } 0 \text { otherwise; } \\
\text { bSTAKEMAX }\end{array}$ \\
$\begin{array}{l}\text { Binary variable equal to } 1 \text { if the firm's management says it wants to } \\
\text { maximize stakeholder value (shareholders, employees, customers, } \\
\text { environment, etc.), and equal to } 0 \text { otherwise. }\end{array}$ \\
\hline
\end{tabular}




\section{Table 6}

Relation between DCF firm valuation and shareholder value maximization

The table examines the relation between the DCF firm valuation method and the target of shareholder value maximization. The analysis is based on the survey of 1998 and is performed with a logistic regression. Each column reports the estimated regression coefficients for one particular specification and (in parentheses) the associated p-value for a two-sided test of difference from zero. The dependent variable is bDCFVALUATION, a dummy variable equal to 1 if managers say they use a DCF approach when valuing firms, and equal to 0 if they do not say so.

\begin{tabular}{|c|c|c|c|}
\hline \multirow[t]{4}{*}{ Independent variables } & \multicolumn{3}{|c|}{ Logistic regression coefficients } \\
\hline & \multicolumn{3}{|c|}{ Dependent variable: $b D C F V A L U A T I O N$} \\
\hline & All firms & Unlisted firms & Listed firms \\
\hline & (1) & (2) & (3) \\
\hline Constant & $\begin{array}{c}0.202 \\
(0.773)\end{array}$ & $\begin{array}{l}-0.021 \\
(0.977)\end{array}$ & $\begin{array}{c}9.061 \\
(0.795)\end{array}$ \\
\hline bNPV & $\begin{array}{c}0.890 \\
(0.004)\end{array}$ & $\begin{array}{c}0.780 \\
(0.019)\end{array}$ & $\begin{array}{c}2.066 \\
(0.048)\end{array}$ \\
\hline bLISTED & $\begin{array}{c}0.912 \\
(0.063)\end{array}$ & & \\
\hline LNSIZE & $\begin{array}{c}0.139 \\
(0.223)\end{array}$ & $\begin{array}{c}0.166 \\
(0.176)\end{array}$ & $\begin{array}{l}-0.007 \\
(0.984)\end{array}$ \\
\hline bSHAREMAX & $\begin{array}{c}0.420 \\
(0.180)\end{array}$ & $\begin{array}{c}0.605 \\
(0.073)\end{array}$ & $\begin{array}{l}-1.387 \\
(0.265)\end{array}$ \\
\hline bSTAKEMAX & $\begin{array}{l}-1.443 \\
(0.002)\end{array}$ & $\begin{array}{l}-1.411 \\
(0.003)\end{array}$ & $\begin{array}{l}-7.829 \\
(0.822)\end{array}$ \\
\hline Cox \& Snell $\mathrm{R}^{2}$ & 0.135 & 0.095 & 0.178 \\
\hline $\begin{array}{l}\text { Overall percentage of correctly } \\
\text { predicted cases }\end{array}$ & $68.5 \%$ & $63.4 \%$ & $84.1 \%$ \\
\hline Number of observations & 219 & 175 & 44 \\
\hline
\end{tabular}

\begin{tabular}{ll}
\hline Variable Definitions & \\
\hline bDCFVALUATION & $\begin{array}{l}\text { Binary variable equal to } 1 \text { if management says it values firms with a } \\
\text { DCF approach, and equal to 0 otherwise; } \\
\text { bNPV }\end{array}$ \\
$\begin{array}{l}\text { Binary variable equal to } 1 \text { if management claims to use NPV when } \\
\text { making investment decisions, and equal to 0 otherwise; } \\
\text { bLISTED }\end{array}$ & $\begin{array}{l}\text { Binary variable equal to } 1 \text { if the firm is listed on the Swiss stock } \\
\text { exchange, and equal to } 0 \text { otherwise; } \\
\text { Natural logarithm of firm size, measured by the number of firm } \\
\text { employees; } \\
\text { Binary variable equal to } 1 \text { if the firm's management says it wants to } \\
\text { maximize stakeholder value (shareholders, employees, customers, } \\
\text { environment, etc.), and equal to 0 otherwise; } \\
\text { Binary variable equal to } 1 \text { if the firm's management says it wants to } \\
\text { maximize shareholder value, and equal to } 0 \text { otherwise. }\end{array}$ \\
bSHAREMAX &
\end{tabular}




\section{Table 7}

Relation between stock price performance, firm targets, and valuation methods

The table examines the relation between stock-price performance, the targets managers claim to pursue, and the valuation methods they use when making investment decisions. The analysis is based on the 1998 survey. The investigation is performed with an ordinary least squares regression. The dependent variable, abnormal stock price performance, is the intercept estimate (cumulated over 72 months) in the following regression equation:

$$
\mathrm{R}_{\mathrm{it}}-\mathrm{R}_{\mathrm{Ft}}=\alpha_{\mathrm{i}}+\beta_{\mathrm{i}} \times\left(\mathrm{R}_{\mathrm{Mt}}-\mathrm{R}_{\mathrm{Ft}}\right)+\varepsilon_{\mathrm{it}},
$$

where the variables are defined as follows:

$$
\begin{array}{ll}
\mathrm{R}_{\mathrm{it}} & =\text { the continuously compounded return on the stock of firm } \mathrm{i} \text { during month } \mathrm{t} ; \\
\mathrm{R}_{\mathrm{Ft}} & =\text { the continuously compounded risk-free rate of return during month } \mathrm{t} ; \\
\mathrm{R}_{\mathrm{Mt}} & \text { the continuously compounded return on the Morgan Stanley Composite Index } \\
& =\text { Europe } 15 \text { (MSCI-E } 15) ; \\
\varepsilon_{\mathrm{it}} & \text { a serially uncorrelated, normally distributed error term with zero mean and constant } \\
\alpha_{\mathrm{i}} \text { and } \beta_{\mathrm{i}}= & \text { the regression intercept and slope coefficients, respectively. }
\end{array}
$$

The regression is estimated with monthly data over the period January 1996-December 2001 with the robust regression approach implemented in the statistical package Stata 7. Each column in the table reports the estimated regression coefficients for one particular specification and (in parentheses) the associated p-value for a two-sided test of difference from zero.

\begin{tabular}{lccc}
\hline Independent variables & $(1)$ & $(2)$ & $(3)$ \\
\hline Constant & -1.345 & -0.663 & -1.373 \\
& $(0.002)$ & $(0.043)$ & $(0.002)$ \\
bSHAREMAX & 0.381 & 0.375 & \\
bSHAREMAX*RETNEG & $(0.108)$ & $(0.167)$ & 0.474 \\
bSHAREMAX*RETPOS & & & $(0.124)$ \\
& & & 0.265 \\
bNPVLARGE & & & $(0.305)$ \\
bPAYBACKLARGE & 0.057 & 0.133 & -0.028 \\
bDCFVALUATION & $(0.792)$ & $(0.582)$ & $(0.899)$ \\
bASSETVALUATION & & & 0.862 \\
CLOSELYHELD95 & $(0.861$ & & $(0.032)$ \\
OWNERSHIPCHANGE & & -0.057 & \\
& $(0.548)$ & $(0.825)$ & \\
F-value & 1.148 & 0.025 & \\
Adjusted R & $(0.017)$ & $(0.955)$ & 1.041 \\
Number of observations & & 0.939 & $(0.021)$ \\
\hline
\end{tabular}




\begin{tabular}{|c|c|}
\hline Variable Definitions & \\
\hline bSHAREMAX & $\begin{array}{l}\text { Binary variable equal to } 1 \text { if the firm's management says it wants to } \\
\text { maximize shareholder value, and equal to } 0 \text { otherwise; }\end{array}$ \\
\hline bSHAREMAX*RETNEG & $\begin{array}{l}\text { Binary variable equal to } 1 \text { if managers say they maximize shareholder } \\
\text { value and the company in question experiences a negative return during } \\
\text { January 1990-December 1995; otherwise, the variable is equal to } 0 \text {; }\end{array}$ \\
\hline bSHAREMAX*RETPOS & $\begin{array}{l}\text { Binary variable equal to } 1 \text { if managers say they maximize shareholder } \\
\text { value and the company in question experiences a positive return during } \\
\text { January } 1990 \text {-December 1995; otherwise, the variable is equal to } 0 \text {; }\end{array}$ \\
\hline bNPVLARGE & $\begin{array}{l}\text { Binary variable equal to } 1 \text { if management says NPV is the deciding } \\
\text { criterion for large investment projects, and equal to } 0 \text { otherwise; }\end{array}$ \\
\hline bASSETVALUATION & $\begin{array}{l}\text { Binary variable equal to } 1 \text { if management says it values firms by } \\
\text { looking at the value of their individual assets, and equal to } 0 \text { otherwise; }\end{array}$ \\
\hline bDCFVALUATION & $\begin{array}{l}\text { Binary variable equal to } 1 \text { if management says it values firms with a } \\
\text { DCF approach, and equal to } 0 \text { otherwise; }\end{array}$ \\
\hline CLOSELYHELD95 & $\begin{array}{l}\text { Binary variable equal to } 1 \text { if the firm has a shareholder with more than } \\
50 \% \text { of the votes in } 1995 \text {, and equal to } 0 \text { otherwise; }\end{array}$ \\
\hline OWNERSHIPCHANGE & $\begin{array}{l}\text { Change in the percentage stake of the shareholder with more than } 50 \% \\
\text { of the votes between } 1990 \text { and } 1995 \text {. }\end{array}$ \\
\hline
\end{tabular}

